\title{
Nineteenth Century New Zealand Novels and Novellas Published as Serials in New Zealand, Australian and British Newspapers and Periodicals and Never Published as Monographs: A Checklist. Addendum
}

\author{
J.E. TRAUE
}

The original checklist of 114 titles was published in the Journal of New Zealand Studies 20 (2015): 10-23. This addendum lists a further 10 titles, all published in New Zealand newspapers and periodicals.

\section{Collins, Edward}

Love and War.

(set in Taranaki wars)
Oxford Observer, 29 Dec 1894-

19 Jan 1895

(4 instalments)

De Lisle (or De L'Isle), Fabian D’Aquilar Chavasse Dudley, 1861-1938. Born U.K., lived in India, New Zealand, c.1893-1911, and Australia, where he was known as Frankland D'A. C. De Lisle. Journalist, music teacher in Hastings, 1897. Stories published in U.K., New Zealand and Australian newspapers. Author of The Adventures of a Turf Detective (London, 1910), and The Adelaide Polo Club (Adelaide, 1913).

A Scion of the Kumpani Bahadur. A Tale of Indian Sport. Specially Written for the Hastings Standard.

(“...the story will be published by Messrs

Unwin Fisher \& Co, London")

Dixi, pseud.

Maud's love Story. Specially Written for the Witness Ladies’ Page, By Dixi.

\section{Flint, Frederick Lindsay Crawford}

The Old and the New; or, Why Did He Not Succeed. By Craw Linn.

Juggle, Sir Volius, pseud.

2001 Anno Domini. A Sequel. By Sir Volius Juggle

Observer (Auckland), 9 Nov-7 Dec 1889

(5 instalments)

Hastings Standard, 18 Jan-16 Feb 1897.

(26 daily instalments)

Otago Witness, 21 Mar-2 May,1889

(7 instalments)

Saturday Advertiser, 2 Feb-18 May 1878.

(15 instalments) 
Lusk, Hugh Hart, 1837-1926. Author of A Rolling Stone, identified as H. H. L. in Chapman's New Zealand Publications: A Descriptive List of Works (Auckland: William Atkin, 1869).

A Rolling Stone.

(a parody of a Wilkie Collins novel)
Chapman's New Zealand Monthly Magazine, Oct-Dec 1882

(3 instalments)

Rattray, Lizzie Frost (Fenton), 1855-1931

Captain Alten's Torpedo Expedition. An Incident of the War in 1891. By Mrs W. Rattray.

Satchell, William Arthur, 1860-1942.

The Other Inmate. By Samuel Cliall White.

The Stone Stable Mystery. By Samuel Cliall White.

The Stone Stable Mystery. (no author given)

\section{Suisted, Laura Jane}

Coniston Hall: A Dark Page in its History. By Laura
Waikato Times, 13 Oct-3 Nov 1888 (5 instalments)

Evening Star, 8 Feb-11 Apr 1896;

Press, 15 Feb-18 Apr 1896

Maorilander, Feb 8, 15, 22;

Mar 15, 22, 1901

(5 instalments, "to be continued")

New Zealand Graphic, Apr 23-May 14, 1904 (4 instalments, completed)
New Zealand Public Opinion, 26 Feb-19 Mar 1881

(4 instalments) 